Bond University ePublications@bond

Sports Law eJournal

Faculty of Law

$8-19-2015$

\title{
The union of European football association's club licensing and financial fair play regulations - are they working?
}

Neil Dunbar

James Cook University Australia

Follow this and additional works at: http://epublications.bond.edu.au/slej

Part of the Entertainment, Arts, and Sports Law Commons

\section{Recommended Citation}

Neil Dunbar. (2015) "The union of European football association's club licensing and financial fair play regulations - are they working?" „, : ISSN 1836-1129.

http://epublications.bond.edu.au/slej/27 


\title{
The union of European football association's club licensing and financial fair play regulations - are they working?
}

\begin{abstract}
Good governance of sport is of the highest importance, particularly in professional team sports, which require large expenditure to maintain a club's position in a league. This has led to a number of clubs, such as Portsmouth in the English Premier League, being forced into administration. Furthermore, the Global Financial Crisis has emphasised the need for more appropriate and robust corporate governance, including for sporting bodies. The Union of European Football Association (UEFA), under its president, Michel Platini, has introduced Club Licensing and Financial Fair Play Regulations. They aim to bring greater security and financial viability to the management of European football. These Regulations focus on the non-payment of liabilities to other clubs, employees, and players, and the break-even requirement. These changes emphasise the need for European football clubs to meet their financial commitments in a timely manner and operate their clubs within their income revenue, rather than from loans or investments from wealthy club patrons or owners. The regulations seek to bring financial integrity and stability to European football. The Regulations seem to have achieved this and have generally been accepted by the clubs, but they are under legal challenge before the European Court. Meanwhile, the use of the Regulations in Australia would not be appropriate, as Australian sports, including football, have developed indirect means of curbing the financial spending of clubs through the use of salary and transfer fee caps.
\end{abstract}

\section{Keywords}

UEFA, club licensing regulations, financial fair play regulations, football financesa

\author{
Disciplines \\ Entertainment, Arts, and Sports Law
}




\title{
THE UNION OF EUROPEAN FOOTBALL ASSOCIATION'S CLUB LICENSING AND FINANCIAL FAIR PLAY REGULATIONS - ARE THEY WORKING?
}

\author{
NEIL DUNBAR*
}

\begin{abstract}
Good governance of sport is of the highest importance, particularly in professional team sports, which require large expenditure to maintain a club's position in a league. This has led to a number of clubs, such as Portsmouth in the English Premier League, being forced into administration. Furthermore, the Global Financial Crisis has emphasised the need for more appropriate and robust corporate governance, including for sporting bodies. The Union of European Football Association (UEFA), under its president, Michel Platini, has introduced Club Licensing and Financial Fair Play Regulations. They aim to bring greater security and financial viability to the management of European football. These Regulations focus on the non-payment of liabilities to other clubs, employees, and players, and the break-even requirement. These changes emphasise the need for European football clubs to meet their financial commitments in a timely manner and operate their clubs within their income revenue, rather than from loans or investments from wealthy club patrons or owners. The regulations seek to bring financial integrity and stability to European football. The Regulations seem to have achieved this and have generally been accepted by the clubs, but they are under legal challenge before the European Court. Meanwhile, the use of the Regulations in Australia would not be appropriate, as Australian sports, including football, have developed indirect means of curbing the financial spending of clubs through the use of salary and transfer fee caps.
\end{abstract}

\section{INTRODUCTION}

Football has implemented labour market controls over the years to control both payments and movements of players. ${ }^{1}$ While retain and transfer systems and maximum wages for players are no longer utilised, a more limited transfer system based on the contractual arrangements between club and player remains in place. It should be noted that, like other sports, there is interdependence between the clubs within football. The clubs need each other to provide competition and they also need to have some certainty over player availability so that they have a chance of developing a matchwinning squad. This is why football has had market controls and recently the Union of European Football Associations (UEFA) has introduced its Club Licensing and Financial Fair Play Regulations (the Regulations) which can be viewed as an indirect salary cap. ${ }^{2}$

This paper will, therefore, consider the impact of the Regulations, not only on the clubs, but also on individuals and groups associated with the clubs, including players, agents and spectators. It provides an overview of the Regulations with special attention being given to the main financial provisions. Some examples will be provided to show the impact of the Regulations on clubs while an assessment of the Regulations will then be made in regard to the two most important financial areas, namely overdue payables and the break-even requirement. A consideration of the complaints to the European Commission (EC) and legal proceedings commenced against UEFA in relation to the Regulations will then be undertaken. Finally, it will examine the potential application of similar rules to Australian football. Firstly, however, this paper will deal with the background to the advent of the Regulations.

\section{THE FINANCES OF EUROPEAN FOOTBALL CLUBS}

The background to the Regulations arose out of the concern for the financial position of football clubs. European football went through a period of major expansion, which began in or about 1992 when the newly formed English Premier League (EPL) secured a $\$ 115 \mathrm{~m}$ television rights deal with Rupert Murdoch's Sky TV. ${ }^{3}$ At the same time the advent of technology exposed the football clubs to a much wider audience. Business entrepreneurs saw the potential

* Neil Dunbar, Lecturer, College of Business, Law and Governance, James Cook University, Townsville, Queensland, Australia.

1 See Chris Davies, Labour Market Controls and Sport in Light of UEFA's Financial Fair Play Regulations (2012) 10 European Competition Law Review 435; and Chris Davies, Football's Transfer Post-Bosman: Freedom of movement for players versus football's financial future? (2014) 10 European Competition Law Review 8.

2 Chris Davies, Labour Market Controls and Sport in Light of UEFA's Financial Fair Play Regulations (2012) 10 European Competition Law Review 435.

3 Andrew Nixon, 'Daniel Striani and Uefa's Financial Fair Play regulations: the new Bosman?' 1 March 2015, www.sportingintelligence.com; See also Andrew Wenger, 'UEFA Financial Fair Play' 27 December 2012 Soccer Politics/The Politics of Football < http://sites.duke.edu/wcwp/2012/12/27/uefa-financial-fair-play/>. 
to make large sums of money from an industry which was basically unregulated, and if a successful team could be established then there was a real chance of a potential financial windfall. A number of clubs became funded by wealthy individuals, such as Chelsea and Manchester City. However, not all of these clubs can be successful in any one season, with, for instance, only one club being able to win the UEFA Champions League. In 2009 UEFA researched the 655 European football clubs and discovered that more than $50 \%$ of them had run at a loss over the previous year. ${ }^{4}$ UEFA also discovered that some clubs had large outstanding debts to creditors, which included sums due to other clubs for transfer fees. There was the potential for financial chaos to arise if efforts were not made to remedy the position.

Portsmouth, for instance, is a club who sought success but ultimately paid a large price for its owner's ambition. Alexandre Gaydamak purchased the club in 2006, and with the aid of his capital and bank loans, the club was able to assemble a squad of star players. Under the management of Harry Redknapp, Portsmouth managed to secure a top half finish in the EPL in both 2007 and 2008, as well as winning the FA Cup in 2008. However, the global financial crisis prevented Gaydamak from continuing to finance Portsmouth, ${ }^{5}$ and he subsequently sold the club in 2009 . From that point, the club's fortune declined, apart from the club's surprising reappearance at Wembley for the FA Cup final in May 2010. Debts were increasing and the better players, like Glen Johnson, Peter Crouch, and Sylvan Distin, needed to be transferred. ${ }^{6}$ Due to its financial plight the EPL prevented the club from signing new players. The club was on occasions unable to pay its players and it owed HM Revenue and Customs money for outstanding taxes.

Portsmouth went into administration in early 2010 with debts in the region of $£ 135 \mathrm{~m}$ and received an automatic nine penalty point deduction from the EPL, which contributed to the club's relegation in May 2010. Since that time Portsmouth has had a succession of new owners and has also suffered a further two relegations. It managed to exit its initial administration only to return into administration in 2012. It is currently out of administration once again and being run comparatively successfully, but at a relatively lower and more temperate level, by the Pompey Supporters' Trust. $^{7}$

Glasgow Rangers is another high profile example of a club which became involved in debt in an effort to keep itself at the forefront of Scottish football. By 2009 the debt owed to its bank, Lloyds Banking Group, had reached $f^{3} 31 \mathrm{~m} .^{8}$ Rangers were also in dispute with HM Revenue and Customs in respect of an employee benefit trust scheme, which it had set up to avoid tax. The amount in dispute was $f 36.6 \mathrm{~m}$ together with the possibility of penalties and interest being added to the principal sum, if Rangers was found liable. ${ }^{9}$ Pressure was exerted on former owner, Sir David Murray, to sell his $85 \%$ share in the club by the bank, and in May 2011, it was sold to Craig Whyte. ${ }^{10}$ It was subsequently discovered, however, that Whyte had previously been banned from being a director for seven years from $2000 .{ }^{11}$ Whyte was unable to improve the club's financial position and placed the club into administration in February $2012 .{ }^{12}$ Substantial sums were due to HM Revenue and Customs and it was not prepared to support the Company Voluntary Arrangement put forward by Rangers. ${ }^{13}$ The club, therefore, entered liquidation on 31 October 2012. ${ }^{14}$

It was with this background that the UEFA president, Michel Platini, decided to act.

\section{AN OVERVIEW OF THE FINANCIAL FAIR PLAY REGULATIONS}

'A financial fair play concept for the game's well-being'15 was agreed in principle in September 2009 by UEFA's Executive Committee, with the Regulations being approved in May 2010. The Regulations, updated in 2012, ${ }^{16}$ have a

Ibid.

David Conn, 'What's gone wrong at Portsmouth? Ten reasons for the demise of a club' The Guardian 6 February 2010.

Jim Holden, 'Portsmouth highlight the rotten culture of football' The Express 25 April 2010.

Dominic Field, ‘Portsmouth's revival owes everything to care of their community' The Guardian 18 April 2014.

Ian Fraser, 'Rangers fans threaten Lloyds Bank with boycott' Shredded 6 May 2010.

Grant Russell, 'Rangers oldco victory in big tax case contained 'errors' in law' STV News 24 February 2014. Note the dispute went to the First-Tier Tribunal, which found that the payments to the trusts could in the majority of cases could be treated as loans and, therefore, no tax was payable. The First-Tier Tribunal did find that in five cases the payments were wages and were liable to tax. HM Revenue and Customs appealed the decision. In July 2014 the appeal was dismissed by Lord Docherty in the Upper Tier Tribunal, although the judge did refer matters relating to termination and 'guaranteed bonus' payments back to the First-Tier Tribunal for reconsideration. HMRC has lodged an appeal against the decision of the Upper Tier Tribunal but this has not been heard yet.

10 Douglas Fraser, 'Rangers' liquidation Q\&A' BBC News 12 June 2012. Sir David Murray sold his share to Craig Whyte on the basis that he would pay off the debt of $f, 18 \mathrm{~m}$ to Lloyds Bank from his own funds. Whyte actually paid off the debt by selling off future season ticket sales. In effect Rangers funded the purchase of its own shares. In February 2015 Craig Whyte was banned from holding a directorship for 15 years for his 'singularly shocking and reprehensible' conduct and 'for failing to avoid conflict of interest in the running of the club.'

11 Grant Russell, 'Former Rangers owner Craig Whyte facing fresh directorship ban' STV News 14 May 2014.

12 BBC News, 'Rangers FC signals intent to go into administration' 13 February 2012.

13 BBC News, 'Old Rangers set for liquidation as administration process ends' 17 October 2012.

14 BBC News, 'Lord Hodge approves liquidation of former Rangers FC' 31 October 2012.

15 UEFA, 'Financial Fair Play' 12 January 2015 <http://www.uefa.org/protecting-the-game/financial-fair-play/index.html>.

16 Ibid. 
number of general objectives including, inter alia, promoting and improving the standard of football in Europe with priority for the training and care of young players, ensuring clubs have adequate management and organization and well-equipped and safe facilities, protecting the integrity and smooth running of the UEFA club competitions and allowing the development of benchmarking for clubs in financial, sporting, legal, personnel, administrative and infrastructure related criteria throughout Europe. ${ }^{17}$ These objectives are dealt with in the body of the regulations under Chapter 3, entitled 'Licensing Criteria'. Article 16 states that the Licensing Criteria referred to in Chapter 3 must be met before a club will be granted a licence to enter the UEFA club competitions. ${ }^{18}$

There are also a series of financial objectives, which have the overall aim of achieving financial fair play in UEFA club competitions. These individual financial objectives comprise improving the financial capability of clubs, protecting clubs' creditors and the long-term viability and sustainability of European club football, introducing more discipline and rationality in club football finances, and encouraging clubs to operate within their own revenues and responsible spending for the long-term benefit of football. ${ }^{19}$ These financial objectives are underpinned by the regulations contained within the Financial Criteria of Chapter 3 with clubs being required to meet the stated requirements.

While the Regulations are extensive, the two areas with the most financial impact on clubs are those which cover the no overdue payable provisions towards other football clubs, ${ }^{20}$ employees and/or social/tax authorities, ${ }^{21}$ and the break-even requirement. ${ }^{22}$

The non-payment of outstanding liabilities by clubs is a relatively straight-forward concept to understand, as is the unfair element associated with it. If a club uses players, which it does not pay or is unable to pay, then it is gaining an unfair advantage against other clubs in the competition, which are abiding by the terms of their player contracts and, therefore, the competition rules. A club adopting this approach is using inputs 'under false pretenses and in doing so reaps unjust rewards. ${ }^{23}$ Similarly, the same unfair advantage occurs if a club fields a player whose transfer fee has not been paid since use of players in these circumstances is similar to fielding a player under suspension and, therefore, interferes with the 'integrity of the competition'. ${ }^{24}$

A monitoring process was incorporated into the Regulations to deal with the issue of 'overdue payables' and this did not give clubs the same leeway with regard to payment time as existed prior to the Regulations. Previously this information would only be revealed in its annual accounts so a club could take advantage of the lengthy time periods that arise when accounts are only prepared every twelve months and be under no pressure to pay the sum or sums due. The potential twelve month period could also be extended because the club would not be in breach of the then rules unless it had not paid the debt by the time it applied for its next licence on 31 March. Thus a club potentially had a period of up to fifteen months before it needed to pay its debt. Under the current Regulations this long period of grace is no longer available. Articles 65 and 66 of the current Regulations provide further cut-off dates of 30 June and 30 September, deadlines by which clubs must have no outstanding sums due to other clubs, its employees, or social/tax authorities. Clubs are required to provide a declaration to this effect within fourteen days of each cut-off period. ${ }^{25}$

The break-even requirement can be simply described as requiring each club to balance its books. That is, each club is expected to cover its expenses with its revenue. The ethical argument behind this rule is the unfair advantage that rich benefactors can bring to a club simply through the provision of money. It can be seen as unethical because the funding

17 UEFA Club Licensing and Financial Fair Play Regulations (2012) 2.

18 Some matters referred in Chapter 3 will not prevent the issue of a licence but will incur a sanction as prescribed under article 8. Such sanctions include, inter alia, a caution or a fine and include issues like the appointment of a supporter liaison officer or youth coach. Note also in relation to English football that the Football Association and the Football League have implemented measures to ensure that even at domestic level clubs need to comply with these regulations. Queens Park Rangers, who are currently fighting to avoid relegation from the EPL, are the latest club to face a potential punishment from failing to meet a 'breakeven' requirement. Although presently in the EPL, Queens Park Rangers was only promoted to that league in May 2014. The club's difficulties are in relation to the 'breakeven' provision whilst it was in the Championship Division for the year 2012-13. The 'breakeven' requirement for the Championship for that period allows a permitted loss of $£ 8 \mathrm{~m}$ and while it is not precisely certain, it appears QPR's loss for 2013-14 could be in the region of $£ 65 \mathrm{~m}$. If this figure proves accurate then QPR could face a very substantial financial penalty, which if not paid could lead to QPR being banned from playing in the Championship, should the club be relegated from the EPL.

19 UEFA Club Licensing and Financial Fair Play Regulations (2012) 2.

20 The basic rule is contained in Article 49 of the Regulations.

21 The basic rule is contained in Article 50 of the Regulations.

22 The rules are contained in Article 58 to 63 of the Regulations.

23 J Christian Muller, Joachim Lammert and Gregor Hovemann, 'The Financial Fair Play Regulations of UEFA: An Adequate Concept to ensure the Long-term Viability and Sustainability of European Club Football?' (2012) 7 International Journal of Sport Finance 117, 129 .

24 Ibid.

25 Ibid. The second cut-off date only needs to be adhered to by a club if it has not been able to state that it has no outstanding sums due in its 30 June declaration. 
is provided independently from the 'sporting success, the tradition and reputation of the club.' ${ }^{26}$ This type of revenue is distinguished from other types of revenue such as gate receipts and sponsorship, which will, of course, vary from club to club, but which are seen as effectively a reward to those clubs which have increased in these areas due to their successful performance in the past. $^{27}$

This ethical consideration has influenced how some of the key words in the break-even requirement have been defined. Revenue comprises, inter alia, income from gate receipts, broadcasting rights, sponsorship and advertising. It does not include sums received from wealthy benefactors or even sums received from a benefactor in the guise of a legitimate expense. Thus, if a benefactor completes a sponsorship deal with the club he cannot increase the amount he pays. For the purpose of the break-even requirement a strict market value of the sponsorship is the amount which is taken into account as revenue. Expenses comprise all legitimate operating expenses with certain expenses being given an exemption. These relate to expenses concerning youth development, construction and maintenance of infrastructure and community development activities. ${ }^{28}$

A club's financial performance, however, is affected by its sporting achievements, which can be uncertain, and to overcome this uncertainty, the break-even provisions are applied over a three year period. ${ }^{29}$ A club's deficit from one year can be offset by surpluses in the other years, which means a club meets the requirement of the break-even provision if it has a surplus of revenue over expenses over the three year monitoring period.

There is, however, some latitude in the Regulations. ${ }^{30}$ Firstly, there is a $€ 5 \mathrm{~m}$ allowance for all clubs, which means that any club can have this deficit in respect of any three year monitoring period. ${ }^{31}$ There is also a possibility of a further transitional allowance of up to $€ 40 \mathrm{~m}$, where this sum is covered by a payment or payments from a benefactor(s), which are a gift or for shares in the club. ${ }^{32}$

The overdue payables and the break-even requirement are reasonably straight-forward to understand, as are the reasons for their implementation, as illustrated by the case of Manchester City.

Manchester City was purchased by Sheikh Mansour bin Zayed al Nahyan in September 2009. He is a wealthy man with an estimated net worth of $£, 17$ billion and a family fortune of at least $\$ 1$ trillion. ${ }^{33}$ He purchased the club with a view to making it a major force in European football and apparently earmarked the sum of $f, 500 \mathrm{~m}$ for the sole purchase of buying new players. ${ }^{34}$ It was estimated that by 2010, which was the year that the Regulations came into force, Sheikh Mansour's support for Manchester City could have exceeded $f, 650 \mathrm{~m}$. Therefore every likelihood that the large spending of Sheikh Mansour would mean that Manchester City would find itself in difficulties with the new regulations and, in particular, the break-even provision. This was indeed the case with Manchester City disclosing losses of $£_{1} 153 \mathrm{~m}$ for the 2011-12 and 2012-13 seasons and UEFA consequently putting forward penalty proposals for

26 Muller, Lammert and Hovemann, above n 23, 123.

27 Real Madrid and Manchester United are examples of clubs which have increased support due to success in previous years. Real Madrid won the European Cup (precursor to the UEFA Champions League) five times between 1956 and 1960. Manchester United has won the English Premier League 13 times since 1992.

28 These exceptions are seen as ethically acceptable, as they are encouraging the sustainable and long-term growth of the club, as opposed to sums provided to buy players with the view to obtaining short-term playing success for the club.

29 It will normally be assessed over a three year period but the first monitoring period in the licence season 2013/14 only covers two reporting periods, 2012 and 2013.

30 The two main allowances are mentioned in this paragraph but there are others. Under article 63(2)(b) it is possible to take into account the two years prior to the monitoring period, using any surplus in those two years against any deficit in the monitoring period. Other possible allowances are referred to in Annex XI and include, inter alia, the impact of changes in exchange rates, debt situation and force majeure. There is also a possible transitory allowance in respect of the first two monitoring periods of 2013/14 and 2014/15 only relating to players under contract with the club prior to 1 June 2010.

31 The rationale behind this allowance is that it is not a sum of significance and if a club is only $€ 5 \mathrm{~m}$ in deficit it is not of material consequence.

32 The amount allowed from a benefactor is $€ 40 \mathrm{~m}$ in the first monitoring period $(2014 / 15)$ and $€ 30 \mathrm{~m}$ in the next three monitoring periods (2015/16, 2016/17, and 2017/18). No transitional figure has been fixed for the 2018/19 monitoring period but the transitional amount is expected torun on a descending scale down to an eventual figure of zero.

33 Louise Armistead, 'Sheikh Mansour bin Zayed Al Nahyan has a deep love of sports and deeper pockets' The Telegraph 2 September 2008.

34 Jason Burt, 'Sheikh Mansour's blueprint for success at Manchester City could cost rivals dear' The Telegraph 3 September 2010. 
the club to accept. ${ }^{35}$ The club felt that the suggested penalties were unfair ${ }^{36}$ but eventually decided to accept them, ${ }^{37}$ rather than contest the issue before the adjudicatory chamber of UEFA's Club Financial Control Body. ${ }^{38}$ The agreed penalty comprised a fine of approximately $£, 50 \mathrm{~m}$ of which two-thirds would be suspended, if the club had maximum break-even deficits of $£ 16.2 \mathrm{~m}$ for the $2013-14$ and $£ 8.1 \mathrm{~m}$ in $2014-15 .{ }^{39}$ In addition the club could only register 21 players for the Champions League competition in 2014-15 and had to avoid increasing the amount of the club's salaries to all their employees during $2015 .{ }^{40}$ The club also agreed to limit its spending in the transfer market until the start of the $2014 / 15$ season to a net figure of $f 49 \mathrm{~m} .{ }^{41}$

Paris St Germain was another club that was heavily punished by UEFA for failing to meet the break-even requirement. This club's situation was similar to the position of Manchester City. A wealthy buyer also purchased Manchester City with Qatar Sports Investments acquiring a 70\% controlling interest in the club in 2011 and buying the remaining 30\% a year later. ${ }^{42}$ Similar to Manchester City large sums of money were made available for the purchase of talented players and success was almost instantaneous with the club winning the French League in 2012-13 and 2013-14. Its difficulty with UEFA arose in its sponsorship arrangement with Qatar Tourism Authority ${ }^{43}$ and it was punished in a similar manner to Manchester City. ${ }^{44}$

Having considered examples of how some clubs have been impacted by the Regulations, a general assessment of the Regulations will now be undertaken.

\section{ASSESSMENT OF THE REGULATIONS}

\section{Overdue payables}

UEFA had been monitoring the issue of overdue payables carefully and in August 2012 the UEFA Club Financial Control Body's investigatory chamber withheld prize money from twenty three clubs pending further investigation. ${ }^{45}$ However, in October 2012 the investigatory chamber lifted the suspensions on prize money in respect of sixteen clubs, ${ }^{46}$ with the remaining seven clubs being referred to the adjudicatory chamber together with two other clubs, whose overdue payables balances had worsened. ${ }^{47}$ The adjudicatory chamber met in December 2012 and punished seven of the nine clubs with the threat of suspension from playing one season in the UEFA club competition, if they did not pay all sums outstanding in respect of their overdue payables account by 31 March 2013, plus any fines. ${ }^{48}$

Malaga was punished more severely with an immediate exclusion from the next UEFA club competition, together with a $€ 300,000$ fine and a further suspension from playing in the UEFA competition for another season, if its overdue payables account was not settled by 31 March 2013.49 Malaga decided to appeal its suspension to the Court of Arbitration for Sport (CAS), which in June 2013 dismissed Malaga's appeal and upheld UEFA's initially imposed penalty. ${ }^{50}$ UEFA has taken a similar approach with six clubs found to be in breach of the overdue payables regulation

35 Richard Farley 'Manchester City considers challenging UEFA's Financial Fair Play penalty’ ProSoccerTalk 6 May 2014.

36 Manchester City felt that it was unfair that it should be fined a similar amount to Paris St Germain, particularly because the latter's $f, 167 \mathrm{~m}$ deal with Qatar Tourism Authority was found to be a related party transaction, unlike its own agreement with Etihad. The club also disagreed with UEFA's interpretation of some of the club's secondary sponsorship arrangements as not being fair value, and of UEFA's stance to the club's franchise arrangements in New York and Melbourne, which meant that the club could not write-off wages on contracts signed pre-2010. In essence, Manchester City believed that it had complied with the breakeven requirement.

37 Manchester City took a practical view to the situation deciding it was not in the interests of its fans, its partners and its commercial operations to undertake what would be long, drawn-out proceedings and realising that it would certainly be in a breakeven situation for subsequent monitoring periods.

38 Ben Rumsby, 'Manchester City accept world-record $£, 50 \mathrm{~m}$ fine for breach of UEFA Financial Fair Play rules' The Telegraph 16 May 2014.

39 Ibid.

40 This will continue into 2016 if the club fails to meet their break-even targets.

41 Rumsby, above n 38, 1.

42 Le Parisien, 'Le Qatar sans limite' 7 March 2012.

43 The $£ 167 \mathrm{~m}$ per year sponsorship deal was held to be a related party transaction by UEFA as both parties to the agreement were seen as being part of the Qatari state. Due to the link between the parties the arrangements had to be fair value and UEFA deemed that this was not the case in this agreement.

44 Unlike Manchester City, Paris St Germain did not appear to be too upset by the UEFA decision, no doubt accepting that the sponsorship deal was overpriced.

45 UEFA.org, 'Prize money for 23 clubs withheld' 11 September 2012.

46 UEFA.org, 'Prize money for 16 clubs released' 30 November 2012.

47 Ibid. The prize money for these clubs, Lech Poznan and FC Arsenal Kyiv, had not been originally withheld because of the level of their overdue payments.

48 UEFA.org, 'CFCB adjudicatory chamber decisions' 21 December 2012.

49 Ibid. The case against the ninth club, Lech Poznan, was dropped.

50 UEFA.org, 'UEFA welcomes CAS decision on Malaga' 11 June 2013. The Malaga case was viewed as more serious than the others. Several players, including Ruud van Nistelrooy and Santi Cazorta, had threatened legal proceedings due to non- 
during the next accounting period. ${ }^{51}$ The firm and consistent approach adopted by UEFA, together with the favourable outcome received from the CAS decision regarding Malaga, appear to be having the desired impact since UEFA has reported that 'overdue payables... have reduced from $€ 57 \mathrm{~m}$ in 2011 to $€ 9 \mathrm{~m}$ in summer 2013 . The $€ 9 \mathrm{~m}$ of overdue payables on 30 June 2013 represents a 70\% decrease on the $€ 30 \mathrm{~m}$ figure for 2012,52 and by 30 June 2014 the figure for overdue payables had reduced still further to $€ 8 \mathrm{~m} .{ }^{53}$

\title{
Break-even requirement
}

UEFA has already argued that the break-even Regulations have had a positive effect, with UEFA General Secretary, Gianni Infantino, stating in August 2013 that there had been a $€ 600 \mathrm{~m}$ reduction in the aggregate losses of Europe's first division clubs in the last financial year. ${ }^{54}$ This was a $36 \%$ decrease on the previous year's figures and showed that clubs were taking the fair play provisions seriously with 2012-13 being the first year in which the break-even requirement was being monitored. ${ }^{55}$ It was also revealed that 'for the first time since records began in 2006 , revenue growth $(6.9 \%)$ has outpaced wage growth $(6.5 \%)$ '. ${ }^{56}$ The first monitoring of the break-even requirement revealed nine clubs to be in breach of the provision and these clubs were all offered penalties, which they were ultimately prepared to accept. ${ }^{57}$

Manchester City was reluctant to accept its penalty under the break-even requirement, ${ }^{58}$ and it has been further criticized on the grounds that it restricts competition. ${ }^{59}$ UEFA was aware of the potential for this type of argument to surface prior to the Regulations being introduced, and has sensibly sought to liaise with the European Commissioner for Competition (EC) as the Regulations were developed and implemented. ${ }^{60}$ UEFA President, Michel Platini, for instance, met with the Vice-President of the EC on 3 April 2014 with the Vice-President reaffirming his support for the Regulations, ${ }^{61}$ stating that:

\begin{abstract}
All business enterprises, football clubs included, should 'stand on their own two feet' and live within their own means. This is what EU [European Union] State Aid rules are about and this is what financial fair play is about as well. This is nothing more than sound principles of good corporate governance. For this reason, I'm more than happy to re-affirm my support for UEFA's initiatives such as financial fair play, aiming at safeguarding the health of European football and promoting good governance standards in Europe's most popular sport. ${ }^{62}$
\end{abstract}

Subsequently in October 2014 a formal 'Arrangement for Cooperation' was signed by UEFA and the EC for an agreed period of 3 years. ${ }^{63}$ Paragraph 2.7 of the Arrangement specifically states that the Regulations 'contribute to the sustainable development and healthy growth of sport in Europe. ${ }^{\prime 64}$

Despite open support for the Regulations from the EC this has not prevented complaints being made against the Regulations and, in particular, the break-even provision. It is these complaints and the legal proceedings arising from these complaints that will now be examined.

\section{Complaints and legal proceedings in relation to the regulations}

Daniel Striani, a player's agent from Italy but living in Belgium, ${ }^{65}$ issued a complaint with the EC challenging the Regulations on the basis that they seek to restrict competition. ${ }^{66}$ In particular, he argued that the break-even requirement violated basic EU freedoms relating to the movement of capital, workers and services.$^{67}$ From a personal perspective, Striani alleged that the break-even provision was a restraint of trade that would lead to fewer transfers,

payment of wages and the Spanish League had imposed a transfer ban in January 2012 after Malaga had failed to make a payment to Osasuna for Spanish full-back, Nacho Monreal.

$51 \quad$ UEFA.org 'Six clubs sanctioned for overdue payables' 20 December 2013.

52 UEFA.org, 'Financial fair play bearing fruit' 30 August 2013.

53 UEFA.org, 'Update on work of the CFCB investigatory chamber' 5 December 2014.

54 UEFA.org, above n 52, 2.

55 Ibid.

56 Ibid.

57 This article has already considered the two most serious examples of Manchester City and Paris St Germain.

58 This has been referred to earlier in this article.

59 Scott Flaherty, 'EU Soccer Finance Rules face Antitrust Challenge,' Law360 6 May 2013.

60 ESPN,com 'UEFA, European Union agree' 21 March 2012. The EC originally confirmed that the financial fair play regulations met EU law in respect of State Aid and fair competition.

61 UEFA.org, 'Commissioner Almunia reaffirms financial fair play support' 3 April 2014.

62 Ibid 2.

63 European Commission, 'The European Commission and UEFA sign partnership agreement,' 14 October 2014, www.europa.eu The Arrangement for Cooperation was signed on 14 October 2014 and ends on 31 December 2017.

64 Arrangement for Cooperation between UEFA and the European Commission, 14 October 2014, www.uefa.org.

65 Matt Slater, 'How Bosman's lawyer is plotting another football revolution' BBC Sport 1 October 2013.

66 Flaherty, above n 59, 1.

67 Ibid. 
lower player wages and that it would have a financial impact on his business. ${ }^{68}$ In May 2014 the EC provided Striani with a draft response to his complaint. ${ }^{69}$ It stated that the Regulations applied to clubs, that no complaint had been received from any club and that the clubs had been extensively consulted before the Regulations had been implemented, unanimously supporting their introduction. ${ }^{70}$ The EC also noted that Striani had commenced proceedings in the Belgium court system, which gave him an alternative avenue to pursue his claim. ${ }^{71}$ In October 2014 the EC finalised its decision on Striani's complaint advising that it was taking no further action on the basis that 'the Court of Brussels is well placed to ensure compliance with European competition law including by making reference for a preliminary ruling to the European Court of Justice (ECJ). ${ }^{72}$ It is important to note that the decision of no further action was not a formal determination, with 'the rejection of the complaint ... not amount[ing] to a decision that the break even rules are compatible with the competition rules. ${ }^{73}$ In effect, the EC left this decision for the ECJ to make. ${ }^{74}$

Striani's legal claim against UEFA argues that some of the Regulations ${ }^{75}$ and, in particular, the break-even provision, are anti-competitive and negatively impact on his ability to generate an income. ${ }^{76}$ In his claim Striani points out that the break-even provision specifically restricts competition in a number of ways including, inter alia, restricting investment, fossilizing existing market structure, reducing the number of transfers, the transfer values and the number of players under contract with each club, and deflating players' wages and the income of players' agents. ${ }^{77}$ At the general level Striani claims that the break-even provision also breaches the free movement of capital, workers and services. $^{78}$

The first hearing in the Striani case $^{79}$ took place in the Belgium courts on 26 and 27 February 2015 with the decision presently reserved. It is suggested the case could proceed in a number of ways with the Judge possibly siding with UEFA by declaring the Regulations within EU law. Alternatively, the Judge could find for Striani and declare the Regulations incompatible with EU law. It is submitted, however, that both these outcomes are unlikely and that the Judge will probably refer the matter to the ECJ for its consideration. The Judge could also apply some interim measures ${ }^{80}$ as part of his referral if he felt that these were warranted. ${ }^{81}$

Even if the ECJ ultimately decides that the Regulations are uncompetitive, it is still possible for the regulations to be valid. This will occur if UEFA can show compliance with [Article, Treaty]. To do so, UEFA must show that the Regulations are seeking to achieve a legitimate objective ${ }^{82}$ and that they go 'no further than is necessary to achieve such an objective' (the so-called proportionate test). ${ }^{83}$ It is argued that the Court's interpretation of s 101(3) will be crucial to the outcome of the Striani case. The Court may accept the view that the Regulations are seeking to achieve a legitimate objective, namely the viability of European football, and that the break-even requirement is the most appropriate and reasonable way to achieve this. On the other hand, the Court might take a contrary view, considering that the break-even provision 'actually increases sporting imbalance and reduces uncertainty of outcome by making it hard for challenger clubs to get into the "Magic Circle. ${ }^{84}$ Further, the Court might rule that the break-even requirement is not proportionate. In other words, there are less restrictive ways of achieving UEFA's objective than the breakeven provision. Alternative possibilities might include allowing expenditure above a set figure on the basis that it was

68 Slater, above n $65,2$.

69 David Conn, 'UEFA defeats legal challenge to financial fair play rules' www.theguardian.com 21 May 2014.

70 Ibid.

71 Ibid.

72 Jean-Louis Dupont, '29 October 2014 - Press Release,' 31 October 2014, www.fairplayfc.org

73 Conn, above n 69, 1

74 Following receipt of the decision Striani has lodged a complaint with the European Ombudsman for maladministration. Striani maintains that the European Commission was not independent, impartial or objective since the Commissioner had already shown support for the Regulations. This matter is currently being considered by the Ombudsman. LawinSport, "The EU Ombudsman opens an investigation against the EU Commission for Alleged Maladministration regarding the Striani Case (UEFA Financial Fair Play) 23 January 2015. Note also another complaint made by British, French and Belgian fans has also been made to the EC.. This is currently being investigated by the EC. Dupont, above n 72, 1.

75 Ibid. Striani actually supports the overdue payables rule.

76 David Conn, 'Players' agent launches legal threat to UEFA financial fair play rules' 7 May 2013, www.theguardian.com

77 'Changing the game on Football's Financial Fair Play rules' 26 January 2015, www.mishcon.com

78 Ibid. Club owners are restricted in their movement of capital. Players are restricted in their

79 Apparently Striani has been joined by other 'plaintiffs/claimants' comprising 'players' agents and supporters groups (including those of Manchester City).' Andrew Smith, 'Financial Fair play and the Striani Complaint: Where are we now?' 17 February 2015, www.lawinsport.com

80 The Judge could, for instance, increase the allowance for each club for each monitoring period from $€ 5 \mathrm{~m}$ to $€ 10 \mathrm{~m}$.

81 Smith, above n 79,5 .

82 ‘ Does EU agreement with UEFA send out mixed message on competition law scrutiny in football?' 17 October 2014, www.out-law.com

83 Stephen Hornsby, 'UEFA FFPR settlements, Striani complaint and EU law' 8 July 2014, www.mondaq.com

84 Ibid. By 'Magic Circle' Hornsby is referring to those clubs, which have the highest revenues (eg Manchester United, Bayern Munich, Real Madrid) and who he sees as having their positions protected by the break-even requirement. 
guaranteed, thus preventing any club from getting into financial difficulties. This could then be linked to a luxury tax, which could be imposed on those clubs exceeding the set figure with the tax money received being distributed equally among the competition clubs. ${ }^{85}$

It should be noted that as well as the Striani case, a group of Paris St Germain supporters has also issued proceedings in the French courts, likewise seeking a declaration that the Regulations are in violation of EU labour and competition laws and consequently should be rendered null and void. ${ }^{86}$ At present, however, no date has been set for the hearing. ${ }^{87}$

The ECJ is likely to be reviewing the regulations shortly. With this in mind it is appropriate to consider some of the issues that the Court may examine in its review.

\section{DISCUSSION}

There seems to be a general acceptance by the clubs of the Regulations, which, prima facie, seem to take away the biggest threat to them. This has been achieved to a great extent by the way that the Regulations have been introduced by UEFA. UEFA made certain that the clubs were consulted regarding the Regulations and obtained their endorsement to them. UEFA has been transparent with its implementation, making it clear why it was advocating the use of the Regulations and working with the EC to ensure that it had its support for the proposed measures. It has also sought to implement the Regulations gradually. It is suggested that where there has been conflict between clubs and the Regulations, this has arisen over the interpretation of the Regulations rather than in respect of the principles undermining them.

Malaga took its case to the CAS because it felt it had been harshly treated by UEFA in being banned from taking part in the next UEFA competition - its concern was the harshness of the penalty not that the finding of fault was incorrect. Similarly, one of Manchester City's concerns was the fairness of the penalty it received. Manchester City felt that it was unfair that it should be fined a similar amount to Paris St Germain when its main sponsorship agreement with Etihad was held to be acceptable and yet Paris St Germain's main sponsorship deal with the Qatar Tourism Authority was held to be a related party transaction. Manchester City was also concerned with UEFA's interpretation of some of its secondary sponsorship arrangements not being considered fair value. It was, therefore, not questioning the Regulations themselves, but how they were being interpreted for implementation purposes. ${ }^{88}$ The club decided not to pursue the matter further, taking the view that it would be compliant in subsequent monitoring periods. ${ }^{89}$

Another point to consider is that several of the clubs, who have spent heavily on players, appear to have found ways of reconciling their positions with regard to the break-even requirement with some clever foresight and planning. Manchester City, for example, has purchased controlling interests in a Major League Soccer franchise in New York and also the Australian A-league side, Melbourne City, together with a minority share in Yokohama F. Marinos in Japan. ${ }^{90}$ In this way, the club is seeking to expand its brand name to different areas in the world and it has further plans to expand into China, India, South America and Africa. ${ }^{91}$

This is a useful strategy as it gives its major sponsors, like Etihad, bigger markets in which to promote their services. ${ }^{92}$ It is also a sensible ploy because it ties the club's brand name in with clubs in the locality. Manchester City does not have the same recognition in its brand name as its rivals - Manchester United, for instance -so the bonding with clubs in particular areas allows the Manchester City brand to become better known and associated with each locality. These new interests may also be used as 'feeder' clubs for players to move on loan to Manchester City. Frank Lampard, for instance, was contracted to play for New York City in 2015 but has been loaned to Manchester City to play in the 2014-15 EPL season. ${ }^{93}$ The Arsenal manager, Arsene Wenger has suggested that this type of arrangement could be a way of circumventing the Regulations. ${ }^{94}$

Chelsea, whose success in recent years has been due to the financial input from wealthy owner Roman Abramovich, has taken a slightly different route. It has made some shrewd moves in the transfer market as well as used the loaning of players to its maximum advantage. ${ }^{95}$ Players like Juan Mata and David Luiz, for example, have been sold for

85 Jeroen Schokkaert, 'Financial Fair Play, alternative instruments and competitive balance' 27 February 2013, www.footballperspectives.org

86 Kyle Bonn, 'Group of PSG fans sue UEFA hoping to see Financial Fair Play overturned’ ProSoccerTalk 23 January 2015.

87 The Paris St Germain supporters have also issued a complaint to the European Commission in respect of the Regulations.

88 FCbusiness, 'Manchester City Accepts UEFA Settlement Agreement' 19 May 2014.

89 Nick Harris, 'Manchester City confident of meeting Financial Fair Play rules as club report record revenues of $£ 346.5 \mathrm{~m}$ ' Mail Online 4 December 2014

90 Ibid.

91 Ibid.

92 Ibid.

93 'Wenger reveals City concerns,' 3 August 2014, www.sportinglife.com.

94 Ibid. Another example of this is David Villa. He has also signed to play for New York City but has been loaned to Melbourne City to play in the Hyundai A-League.

95 Liam Twomey, 'How Chelsea and Manchester City are battling Financial Fair Play' Goal.com 31 January 2015. 
considerably more than they cost. ${ }^{96}$ During the last three seasons Chelsea have also loaned out at least 30 players, with the majority remaining as loan players, ${ }^{97}$ though both Romelu Lukaku and Kevin de Bruyne have developed to such an extent that they have now been sold for considerable profit. ${ }^{98}$ Meanwhile, goalkeeper Thibaut Courtois, spent three years on loan at Atletico Madrid and is now back at Chelsea playing in its first team and is ranked as one of the best goalkeepers in the world. ${ }^{99}$

In the circumstances, it is perhaps not totally surprising that the main threat to the Regulations has come from other interested parties, such as players' agents and spectators, and not from the clubs. However, it can be argued that the Regulations actually bring security to those interested parties. By seeking to keep a strong financial grip on clubs, the Regulations provide a more solid platform for European football, from which players and agents will be able to earn a reasonable living and spectators enjoy watching their favourite teams play. It has been suggested, however, that the Regulations may simply preserve the status quo, ${ }^{100}$ since the more successful clubs have better revenues, which will provide them with more money to spend on players, thus creating a continuing cycle of those clubs having the best teams. ${ }^{101}$ UEFA has taken a contrary approach, stating the use of the break-even principle as leading 'to a more competitive and sustainable football sector in Europe,'102 with UEFA General Secretary, Gianni Infantino, maintaining that:

Financial Fair Play will encourage competition on a more effective and efficient basis. A policy which encourages clubs to invest in youth academies, community projects, stadia and infrastructure will enable clubs to generate sustainable income in future which will mean they are better placed to compete on the pitch. ${ }^{103}$

Another criticism of the Regulations is that they prevent risk, ${ }^{104}$ since a club is potentially prevented from spending large sums on new players in an effort to find success. The question is whether this is in the interests of football as a whole. Certainly, a wealthy investor may be prevented from spending as Abramovich and Mansour have done. These two owners have had great success but they are very wealthy. It almost certainly requires a person of similar financial worth to have the same chance of success since many less wealthy benefactors have failed, mainly because they did not have sufficient funds to continue funding their clubs to the extent required, ${ }^{105}$ with Rangers and Portsmouth being good examples. It is proposed that the supporters would have preferred a more sustainable approach to the running of those clubs and that it is far better for European football generally that a more measured approach to growth is taken. ${ }^{106}$

The next question to be examined is whether similar regulations would be helpful to Australian football. There are certainly recent examples of financial difficulties within the Australian game. Nathan Tinkler, owner of the Newcastle Jets, has had difficulties paying the club's creditors ${ }^{107}$ and Perth Glory had a problem with its salary cap arrangements and were ruled out of the finals. ${ }^{108}$ However, football in Australia operates in different circumstances to European football and, therefore, the application of the Regulations would not be appropriate in Australia. The basis of the European Regulations is to provide financial security for the clubs by ensuring that they operate within their means. Thus the concept behind the Regulations is that clubs earn more than they spend. In Australia, the Football Federation Australia (FFA) seeks to achieve similar outcomes but uses different methods to do this with there being a much smaller population than in Europe. The smaller population means that there are less clubs involved compared to Europe and consequently there is no need for promotion and relegation between divisions, which forms a major source of competition in European football. With this aspect not apparent in the Australian league, it is essential that the clubs are as evenly matched as possible to create supporter and spectator interest. For this to be obtained greater control over the playing strength of each club needs to be exercised by the FFA and this can be achieved more

96 Juan Mata was purchased for $£ 25 \mathrm{~m}$ and later sold to Manchester United for $£, 50 \mathrm{~m}$. David Luiz was purchased for $£^{23.5 \mathrm{~m}}$ and then sold to Paris St Germain for $£, 37.1 \mathrm{~m}$.

97 Twomey, above n 95, 2.

98 Lukaku was purchased for $£, 10 \mathrm{~m}$ and sold to Everton for $£ 28 \mathrm{~m}$. De Bruyne was purchased for $£ .7 \mathrm{~m}$ and sold to Wolfsburg for $£ 18 \mathrm{~m}$.

99 Twomey, above n 95, 2.

100 Gabrielle Marcotti, 'European Soccer goes feudal’ The Wall Street Journal 10 October 2010, 2.

101 Ibid.

102 Mark Chaplin, 'Financial Fair Play timetable outlined' UEFA.org 3 March 2014.

103 Ibid.

104 Marcotti, above n 100, 3.

105 Examples include Sir David Murray at Rangers and Alexandre Gaydamak at Portsmouth

106 However, the Rugby Union European Champions, Toulon, offer a contrasting example. Its rise to the top has been spectacular with its owner declaring 'that when he had two Euros in the bank he spent four rather than spending one and saving one, despite the fact that he had suffered sleepless nights as a result.' Hornsby, above n 83, 9.

107 'Nathan Tinkler pays Newcastle Jets' debts as A-League club named Mitchell Murphy as CEO' 6 February 2015, www.abc.net.au.

108 Brad Elborough, 'Perth Glory salary cap breach denied by CEO Jason Brewer,' 13 February 2015, www.smh.com.au Note that from a different Code, the Gold Coast Titans recently entered voluntary administration but were subsequently rescued by the NRL stepping in to take over the Club. Adrian Proszenko, 'NRL moved in on Gold Coast Titans after owners couldn’t meet $\$ 1 \mathrm{~m}$ ultimatum,' 25 February 2015 www.smh.com.au. 
successfully by the use of salary caps. The FFA imposed a $\$ 2.55 \mathrm{~m}$ AUD salary cap per club for the 2014-15 season, ${ }^{109}$ which excludes marquee, guest and replacement players. ${ }^{110}$ The use of the salary cap not only assists in keeping the playing ability of each club at a similar level but also keeps the clubs' chief expense of players' salaries down and works in a similar way to the break-even provision that applies in Europe.

Another area where the FFA operates differently to UEFA is on the issue of transfer fees. In Australia, transfer fees are highly regulated with a club transferring a player restricted to a maximum fee of $50 \%$ of the total salary owing to that player for the remaining part of his contract. ${ }^{111}$ In Europe there is no limitation on transfer fees but the general requirement of clubs to meet the break-even requirement will act as a restriction on what clubs are prepared to pay for players. Clubs in Australia are also expected to honour their debts and pay their creditors. ${ }^{112}$ This is a condition of a club's licence to play in its competition. ${ }^{113}$ It can be seen that the FFA monitors overdue payables and has a system in place for dealing with breaches in this area just as UEFA does in Europe. ${ }^{114}$ Although the means of controlling clubs financially in Australia may differ from Europe, Australia has developed appropriate measures to deal with the same issues that the Regulations seek to do in Europe.

\section{CONCLUSION}

The Regulations have been well received by the clubs. This is not surprising. The clubs initially approved the Regulations and UEFA introduced them in a relatively sympathetic manner. UEFA's transparent approach and the non-immediate implementation of the Regulations have given the clubs the opportunity to prepare and adapt for their introduction. It is too early to say whether the Regulations have been a success. The early signs are that they have had the desired effect by encouraging clubs to take a more careful and long-term approach to their finances. Although there has been no challenge to the Regulations from the clubs, apart from Malaga's application to the CAS for review of its penalty for its overdue payables offence, the legal actions of Daniel Striani and the supporters of Paris St Germain still need to be resolved. The use of the Regulations within Australian football is not required since Australia's position is different to that of Europe, with the FFA relying on salary and transfer caps to curb excessive spending by the clubs.

109 ABC News 'A-League clubs to see slight salary cap raise under new pay deal' 1 July 2013.

110 Marquee and guest players are allowed so as to encourage the promotion and development of the game in Australia. The ALeague has introduced the 'junior marquee player' - with the aim of keeping young (under 23) talented players in Australia.

111 Under FFA's National Registration Regulations transfer fees are dealt with under section 10.5. Clause (a) a transfer fee can only be claimed if the player has an existing contract. Clause (b) states that the transfer fee can be no more than $50 \%$ of the total salary owing to the player for the remaining term of that player's current contract.

112 The Australian, 'Tinkler claims fresh start for Jets with debt paid, new CEO' 7 February 2015.

113 Football Federation Australia, 'FFA have urged Hunter Sports Group to address issues at Newcastle Jets' 28 January 2015. Note the recent example of the Newcastle Jets shows how seriously the FFA considers this issue to be. The FFA issued the Newcastle Jets with a show cause notice as the club had not met its deadline of 31 January 2015 to settle its debts. The owner of the club responded quickly to resolve the position so as not to risk losing his club's licence to play in the Hyundai ALeague.

114 'Newcastle Jets owner Nathan Tinkler served with show cause notice by FFA' 3 February 2015 www.theguardian.com 